\title{
O setor de confecção em G oiânia: análise da relação entre trabal ho doméstico e trabalho domiciliar
}

\author{
Jordão Horta Nunes* \\ Andréla Ferreira Campos**
}

\begin{abstract}
R esumo: O setor de confecção emprega intensivamente o trabalho feminino, apresenta uma estrutura heterogênea e compreende uma diversidade de técnicas produtivas. Caracteriza-se pelo predomínio de micro e pequenas empresas, pela competitividade e pela sazonalidade da produção, além da presença de relaçães de terceirização e subcontratação entre empresas de porte diferente ou ligadas a etapas distintas do processo de produção. O dojetivo aqui é considerar, no elo mais precário da rede, que envolve o trabalho de costureiras em oficinas de âmbito familiar ou facções subcontratadas, a relação entre trabalho doméstico e trabalho domiciliar sob o prisma das relaçães de gênero. Partimos de algumas consideraçães sobre o setor de confeç̧ão no Brasil e em Goiás, numa primeira parte, seguida de uma análise com base em pesquisa de enfoque qualitativo realizada em 2005 no bairro de São Judas Tadeu, próximo ao campus II da UFG, em Goiânia, empregando principalmente entrevistas semi-estnuturadas com trabalhadoras na área de confeç̧ão.
\end{abstract}

Palavr as-chave: trabalho doméstico; indústria de confeçãa; trabalho damici liar.

A indústria de confecções, parte do setor têxtil, compreende os segmentos de vestuário e artigos confeccionados. Trata-se de uma indústria tradicional, que requer ocupação intensiva de mão-de-obra e apresenta uma estrutura bastante heterogênea e fragmentada, empregando uma diversidade de técnicas produtivas. O grande predomínio de micro e pequenas empresas no setor tem como principais justificativas o baixo custo de entrada e a facilidade de acesso à tecnologia. Outras características do setor são a competitividade, em virtude das oscilações da moda e da sazonalidade da

\footnotetext{
* Professor da Universidade Federal de Goiás.

** Aluna do curso de graduação em Ciências Sociais - UFG, bolsista no projeto Trabalho, Gênero e Precarização: o Setor de Confecções em Goiânia, coordenado por J ordão Horta Nunes, que contou com auxílio concedido pelo CNPq, com base na recomendação do Comitê de A ssessoramento e de acordo com o estabelecido no Edital CNPq 32/2004 Ciências Humanas, Sociais e Sociais A plicadas.
}

produção, e a presença de relações de terceirização e subcontratação entre empresas de porte diferente ou ligadas a etapas distintas do processo de produção.

A fabricação de uma peça de confecção envolve um processo produtivo com as seguintes etapas: idealização (criação, design), preparação (modelagem, gradeamento, corte), montagem (costura, overloque), acabamento (caseamento, botões, limpeza, passadoria) (cf. A breu, 1986; Castro, 2004). Há uma diversidade de formas de se dividir o processo de produção, fragmentando e heterogeneizando a cadeia, principalmente nas etapas que precedem a costura. Tal característica favorece as redes de subcontratação. 0 emprego de inovações tecnológicas praticamente se restringe às duas primeiras fases, com destaque para as etapas de desenho (uso de sistemas Computer A ided Design CAD) e máquinas operatrizes automatizadas 
para corte (sistemas Computer A ided M anufacturing - CA M ). A lém disso, a apropriação e a incorporação dessas técnicas restringem-se a empresas de maior porte, com produção em larga escala. A etapa de montagem continua predominantemente baseada no trabal ho intensivo de costureiras. A mão-de-obra feminina aparece em toda a cadeia, embora ela seja fortemente predominante no elo em que prevalecem as formas precárias de contração ou subcontratação, ou seja, no trabal ho domiciliar para empresas de confecção, resul tado da "crescente flexibilização do processo produtivo diante de um mercado diversificado, sazonal e em crise permanente" (A breu e Sorj, 1993a), com a finalidade de redução de custos, manutenção dos prazos de entrega e, como sal ientaram A raújo e A morim (2003, p. 297), transferência de riscos (principalmente os decorrentes de flutuações da demanda) da empresa contratante para as facções subcontratadas. A ssim, é na costura que o setor de confecção demonstra sua identidade ocupacional e de gênero, bem como os problemas sociais que lhe são próprios, principalmente em virtude do uso intensivo e precário da mão-deobra. Contudo, é necessário valorizar, para a compreensão da formação do valor na cadeia de confecções, elos que estão a montante da produção, como o design, a negociação com fornecedores e a gestão de marcas, além de fatores que estão a jusante, como coordenação e logística da cadeia de fornecedores.

Considerar a amplitude e a extensão da cadeia de confecção, sobretudo se considerarmos o contexto atual e os resultados da reestruturação produtiva sobre o setor nos últimos vinte anos, excederia, evidentemente, 0 escopo deste trabal ho. 0 objetivo aqui é considerar, no el o mais precário da rede, que envolve o trabal ho de costureiras em oficinas de âmbito familiar ou facções subcontratadas, a relação entre trabalho doméstico e trabalho domiciliar sob o prisma das relações de gênero. Partimos de algumas considerações sobre o setor de confecção no Brasil e em Goiás, numa primeira parte, seguida de uma análise com base em pesquisa de enfoque qualitativo realizada em 2005 no bairro de São J udas Tadeu, próximo ao campus II da UFG, em Goiânia, empregando principalmente entrevistas semi-estruturadas com trabalhadoras na área de confecção. 0 suporte de um estudo de caso não permite, certamente, general izações; a intenção é proporcionar el ementos para comparações com outras pesquisas recentes realizadas em outras regiões, como no Sudeste (A morim, 2003; L eite, 2004; A raújo e A morim, 2001/2002), Sul (Gazzona, 1997; Ruas, 1993) ou N ordeste (M oreira, 1997; Lima, 1996; Lima e Ferreira, 1999; Silva, 1979).

O setor de confecção no Brasil e em Goiás

O B rasil ocupa o quarto lugar na produção da indústria de confecção (L eite, 2004), liderada pela China, embora essa posição não se reflita na hierarquia dos países exportadores do setor. Foi incipiente a participação brasileira no processo de reestruturação produtiva que atingiu 0 setor a partir dos anos 80, gerando demanda pela mão-de-obra barata encontrada nos países periféricos, que se tornaram grandes exportadores na cadeia (China, Hong K ong, Turquia, M éxico). ${ }^{1}$ A contribuição brasileira chegou a declinar durante os anos 90 (de 0,2\% em 1990 para $0,1 \%$ em 2001). A Iguns autores analisaram no caso do setor de confecção no Brasil, a transição de um mercado doméstico fortemente protegido, até 0 final dos anos 80 , para uma exposição à concorrência externa, a partir dos anos 90 , com a forte redução das alíquotas de importação, gerando redução significativa do número de estabelecimentos industriais e de postos de trabal ho no setor (Gorini e Siqueira, 1998; H aguenauer, 2001; L upatini, 2004).

0 setor de confecção vem ocupando, a partir da década de 1980 , um posto destacado na economia do estado de G oiás. 0 cadastro da Secretaria da Fazenda registra, desde 1990 até 2005, a primazia dos setores de vestuário, calçados e artefatos de tecidos, juntamente com o setor de produtos alimentares, no que se refere a número de estabelecimentos industriais (Tabela 1). ${ }^{2}$

\footnotetext{
1. Segundo Prochnik (2002), os países em desenvolvimento (principalmente os asiáticos) predominam como exportadores (60\% das exportações de produtos têxteis e $78 \%$ das exportações de produtos confeccionados, em 2000).

2. A tabela apresenta apenas os três gêneros com maior número de estabelecimentos.
} 
Segundo a A ssociação Goiana de Indústrias de Confecções e Correlatas (A gicon), 0 faturamento anual do setor alcança mais de $R \$$ 200 milhões. Cerca de $60 \%$ das empresas cadastradas na Secretaria do Planejamento do Estado de Goiás encontram-se na capital, Goiânia, que vem ganhando destaque como centro de ocupação de mão-de-obra no setor, embora não registre nenhum estabelecimento de grande porte. A região metropolitana de Goiânia apresenta uma expressiva freqüência de vínculos empregatícios no setor de "confecções", parte do setor da indústria de vestuário. Goiânia registrou, em 2003, 10.328 vínculos formais de trabalho no setor e ocupa a quarta colocação no que se refere a número de vínculos em relação a todos os municípios brasileiros. A importância do setor fica ainda mais evidente quando levamos em conta a proporção de vínculos em relação a todos os demais setores de atividade econômica. E mbora a cidade tenha a maior parte dos trabal hadores formais nos setores da "administração pública, defesa e seguridade social" e "comércio varejista e reparação de objetos pessoais e domésticos", 0 setor de confecção emprega 2,92\% dos vínculos de toda a população economicamente ativa, índice só superado em Fortaleza (5,56\%) se considerarmos as quatro cidades que apresentam maior número de vínculos no setor. Goiânia está na segunda colocação, dentre as grandes cida- des brasileiras, no que poderíamos chamar de taxa de ocupação relativa no setor de "confecção de artigos do vestuário e acessórios" e a quarta na ocupação absoluta.

0 crescimento do número de estabelecimentos e de postos de trabalho no setor formal foi significativo nos últimos dez anos, como indicam as Tabelas 3 e 4.

Evidenciam-se a concentração de micro e pequenas empresas, característica do setor no $B$ rasil, bem como o pequeno número de empresas médias e a ausência de grandes estabelecimentos. Entretanto, o declínio de postos de trabaIho e de estabelecimentos, que caracterizou uma crise no setor decorrente da reestruturação produtiva e da abertura comercial na primeira metade da década de 1990, foi bem menos significativa em Goiânia do que em outras locais, como éo caso da região de Campinas-SP, pesquisada por Â ngelaA raújo e ElaineA morim (2002) (Tabela 5).

A caracterização do setor de confecção como preponderantemente feminino também se manifesta em Goiânia, com taxa superior a 80\% de vínculos ocupados por mulheres, ainda nos anos 90 . N ota-se uma diminuição da diferença nos últimos anos, em que se atinge uma feminização pouco superior a 50\%. A Tabela 3 permite também visualizar uma correlação negativa entre a feminização dos postos e 0 tamanho dos estabelecimentos: em empresas maiores diminui

Tabela 1 - Estado de Goiás: Número e gênero de estabel ecimentos industriais, cadastrados na Secretaria da Fazenda - posição: jun/91, jun/93 , mai/96, mai/99, jan/01, jan/02, jan/03 - 2004.

\begin{tabular}{|c|c|c|c|c|c|c|c|c|}
\hline Especificação & 1991 & 1993 & 1996 & 1999 & 2001 & 2002 & 2003 & 2004 \\
\hline Total & 9261 & 10711 & 11954 & 9420 & 10405 & 11845 & 11809 & 12668 \\
\hline Vestuário, calçados e artef. tecidos & 2619 & 2786 & 3358 & 2343 & 2828 & 3289 & 3304 & 3741 \\
\hline Prod. alimentares & 2484 & 3074 & 3470 & 2989 & 3116 & 3209 & 3968 & 3152 \\
\hline Prod. minerais não metálicos & 887 & 1007 & 1013 & 803 & 819 & 916 & 937 & 943 \\
\hline
\end{tabular}

Fonte: Secretaria da Fazenda do Estado de Goiás

Elaboração: Seplan-GO / Sepin / Gerência de Estatística Socioeconômica - 2005.

Tabela 2 - Capitais brasileiras: N úmero de vínculos nas quatro maiores cidades brasileiras em termos da ocupação no setor de confecção em 2004.

\begin{tabular}{|c|c|c|c|c|}
\hline Cidade & Fortaleza & Goiânia & São Paulo & Rio de Janeiro \\
\hline Número de vínculos & 25.765 & 11.522 & 65.006 & 16.057 \\
\hline \% relativa de vínculos do setor & 5,56 & 2,92 & 1,86 & 0,88 \\
\hline
\end{tabular}

Fonte: elaboração dos autores com base na Rais/MTE 2004 
relativamente a mão-de-obra feminina, enquanto nas microempresas a taxa de feminização fica em torno de $80 \%$. Tais resultados sugerem, de forma similar ao que foi observado por A raújo e A morim em Campinas, que a masculinização dos postos ocorreu em empresas que experimentaram al gum tipo de modernização gerencial ou tecnológica, como já se verificara no setor têxtil e em outros (cf. A raújo e A morim, 2002, P. 286). A predominância de mulheres ainda vigora em estabelecimentos menores, como oficinas domésticas ou facções, onde vigoram as relações de subcontratação e a precarização das relações de trabalho.

Tabela 3 - M unicípio de G oiânia: Número de estabelecimentos industriais no setor de confecção (Divisão 18 da CN A E 95), classificados por número de empregados.

\begin{tabular}{|c|c|c|c|c|c|c|c|c|c|c|c|}
\hline & 1994 & 1995 & 1996 & 1997 & 1998 & 1999 & 2000 & 2001 & 2002 & 2003 & 2004 \\
\hline 0 empregados & 77 & 160 & 136 & 150 & 128 & 133 & 113 & 177 & 178 & 188 & 171 \\
\hline Até 4 empregados & 350 & 426 & 455 & 478 & 521 & 515 & 641 & 685 & 672 & 698 & 720 \\
\hline De 5 a 9 empregados & 149 & 132 & 142 & 161 & 166 & 192 & 226 & 230 & 261 & 271 & 321 \\
\hline De 10 a 19 empregados & 81 & 83 & 77 & 98 & 127 & 135 & 157 & 177 & 182 & 185 & 184 \\
\hline De 20 a 49 empregados & 52 & 51 & 70 & 58 & 69 & 82 & 92 & 85 & 98 & 99 & 115 \\
\hline De 50 a 99 empregados & 9 & 14 & 13 & 15 & 14 & 13 & 10 & 17 & 17 & 23 & 22 \\
\hline De 100 a 249 empregados & 6 & 3 & 4 & 2 & 3 & 5 & 8 & 6 & 5 & 3 & 5 \\
\hline Total & 724 & 869 & 897 & 962 & 1.028 & 1.075 & 1.247 & 1.377 & 1.413 & 1.467 & 1.538 \\
\hline
\end{tabular}

Fonte: Rais (MTE) - Elaboração dos autores.

Tabela 4 - M unicípio de Goiânia: Número de vínculos empregatícios industriais no setor de confecção (Divisão 18 da CNA E 95), classificados por tamanho de estabelecimento.

\begin{tabular}{|c|c|c|c|c|c|c|c|c|c|c|c|c|}
\hline & & 1994 & 1995 & 1996 & 1997 & 1998 & 1999 & 2000 & 2001 & 2002 & 2003 & 2004 \\
\hline \multirow{3}{*}{$\begin{array}{l}\text { Até } 4 \\
\text { empregados }\end{array}$} & Masculino & 67 & 147 & 113 & 147 & 175 & 146 & 239 & 227 & 250 & 258 & 286 \\
\hline & Feminino & 631 & 716 & 748 & 848 & 893 & 867 & 1.057 & 1.143 & 1.117 & 1.162 & 1.192 \\
\hline & Total & 698 & 863 & 861 & 995 & 1.068 & 1.013 & 1.296 & 1.370 & 1.367 & 1.420 & 1.478 \\
\hline \multirow{3}{*}{$\begin{array}{l}\text { De } 5 \text { a } 9 \\
\text { empregados }\end{array}$} & Masculino & 126 & 90 & 146 & 186 & 174 & 221 & 326 & 318 & 402 & 415 & 506 \\
\hline & Feminino & 837 & 781 & 779 & 883 & 893 & 1.084 & 1.216 & 1.227 & 1.307 & 1.360 & 1.633 \\
\hline & Total & 963 & 871 & 925 & 1.069 & 1.067 & 1.305 & 1.542 & 1.545 & 1.709 & 1.775 & 2.139 \\
\hline \multirow{3}{*}{$\begin{array}{l}\text { De } 10 \text { a } 19 \\
\text { empregados }\end{array}$} & Masculino & 186 & 251 & 199 & 265 & 317 & 399 & 502 & 499 & 568 & 674 & 687 \\
\hline & Feminino & 923 & 865 & 818 & 1.086 & 1.395 & 1.382 & 1.612 & 1.812 & 1.795 & 1.830 & 1.865 \\
\hline & Total & 1.109 & 1.116 & 1.017 & 1.351 & 1.712 & 1.781 & 2.114 & 2.311 & 2.363 & 2.504 & 2.552 \\
\hline \multirow{3}{*}{$\begin{array}{l}\text { De } 20 \text { a } 49 \\
\text { empregados }\end{array}$} & Masculino & 256 & 312 & 370 & 379 & 491 & 594 & 724 & 635 & 842 & 728 & 987 \\
\hline & Feminino & 1.361 & 1.166 & 1.644 & 1.277 & 1.543 & 1.710 & 1.980 & 1.763 & 2.041 & 2.013 & 2.282 \\
\hline & Total & 1.617 & 1.478 & 2.014 & 1.656 & 2.034 & 2.304 & 2.704 & 2.398 & 2.883 & 2.741 & 3.269 \\
\hline \multirow{3}{*}{$\begin{array}{l}\text { De } 50 \text { a } 99 \\
\text { empregados }\end{array}$} & Masculino & 141 & 255 & 288 & 286 & 259 & 310 & 261 & 379 & 471 & 689 & 531 \\
\hline & Feminino & 426 & 761 & 625 & 700 & 655 & 572 & 449 & 749 & 724 & 813 & 899 \\
\hline & Total & 567 & 1.016 & 913 & 986 & 914 & 882 & 710 & 1.128 & 1.195 & 1.502 & 1.430 \\
\hline \multirow{3}{*}{$\begin{array}{l}\text { De } 100 \text { a } 249 \\
\text { empregados }\end{array}$} & Masculino & 148 & 105 & 121 & 82 & 139 & 214 & 387 & 346 & 317 & 102 & 223 \\
\hline & Feminino & 505 & 260 & 343 & 162 & 288 & 425 & 653 & 588 & 553 & 284 & 431 \\
\hline & Total & 653 & 365 & 464 & 244 & 427 & 639 & 1.040 & 934 & 870 & 386 & 654 \\
\hline \multirow{3}{*}{ Total } & Masculino & 924 & 1.160 & 1.237 & 1.345 & 1.555 & 1.884 & 2.439 & 2.404 & 2.850 & 2.866 & 3.220 \\
\hline & Feminino & 4.683 & 4.549 & 4.957 & 4.956 & 5.667 & 6.040 & 6.967 & 7.282 & 7.537 & 7.462 & 8.302 \\
\hline & Total & 5.607 & 5.709 & 6.194 & 6.301 & 7.222 & 7.924 & 9.406 & 9.686 & 10.387 & 10.328 & 11.522 \\
\hline
\end{tabular}

Fonte: Rais (MTE) - Elaboração dos autores. 
Os níveis de escolaridade predominante no setor em 2004 foram "até o ensino fundamental completo" (52\%) e "até ensino médio completo" $(47 \%) .^{3}$ Embora a taxa de trabalhadores com ensino superior seja muito pequena, é interessante considerar o mesmo resul tado que presenciamos na relação entre tamanho de estabelecimentos e taxa de feminização, ou seja, a taxa relativa de ocupações masculinas aumenta nos níveis superiores de escolaridade, indicando que postos que requerem maior qualificação (aos quais certamente corresponde maior remuneração) são mais ocupados por homens. A desigual dade reaparece no caso dos salários recebidos por trabalhadores do setor no período considerado (Tabela 6). A faixa salarial média

Tabela 5 - Região de Campinas/SP: N úmero de vínculos empregatícios industriais no setor de confecção.

\begin{tabular}{|c|c|c|c|c|c|c|c|c|c|}
\hline & 1990 & 1991 & 1992 & 1993 & 1994 & 1995 & 1996 & 1997 & 1998 \\
\hline Total & 5739 & 4834 & 4216 & 4888 & 4014 & 2838 & 2945 & 2856 & 2481 \\
\hline
\end{tabular}

Fonte: Rais (M TE)

Tabela 6 - M unicípio de Goiânia: Número de vínculos empregatícios industriais no setor de confecção (Divisão 18 da CNA E 95), classificados por faixa sal arial média.

\begin{tabular}{|c|c|c|c|c|c|c|c|c|c|c|c|c|}
\hline & \multirow{3}{*}{$\begin{array}{r}1994 \\
43 \\
\end{array}$} & \multirow{3}{*}{\begin{tabular}{r|}
1995 \\
44 \\
\end{tabular}} & \multirow{3}{*}{\begin{tabular}{r|}
1996 \\
25 \\
\end{tabular}} & \multirow{3}{*}{$\begin{array}{r}1997 \\
22 \\
\end{array}$} & \multirow{3}{*}{$\begin{array}{r}1998 \\
34 \\
\end{array}$} & \multirow{3}{*}{\begin{tabular}{r|}
1999 \\
30 \\
\end{tabular}} & \multirow{3}{*}{\begin{tabular}{r|}
2000 \\
56 \\
\end{tabular}} & \multirow{3}{*}{\begin{tabular}{r|}
$\mathbf{2 0 0 1}$ \\
52 \\
\end{tabular}} & \multirow{3}{*}{\begin{tabular}{r|}
2002 \\
62 \\
\end{tabular}} & \multirow{3}{*}{\begin{tabular}{r|}
2003 \\
60 \\
\end{tabular}} & \multirow{3}{*}{$\begin{array}{r}2004 \\
57\end{array}$} \\
\hline & & & & & & & & & & & & \\
\hline De 0 a 1 & Masculino & & & & & & & & & & & \\
\hline salário mínimo & Feminino & 42 & 38 & 31 & 25 & 37 & 70 & 80 & 85 & 134 & 127 & 145 \\
\hline \multirow{2}{*}{$\begin{array}{l}\text { De } 1,01 \text { a } 1,5 \\
\text { sal. mínimo }\end{array}$} & Masculino & 342 & 437 & 464 & 440 & 525 & 605 & 773 & 867 & 1.405 & 1.666 & 1.906 \\
\hline & Feminino & 1.140 & 1.066 & 1.233 & 1.178 & 1.382 & 1.464 & 1.768 & 2.241 & 3.671 & 4.651 & 5.047 \\
\hline \multirow{2}{*}{$\begin{array}{l}\text { De } 1,51 \text { a } 2 \\
\text { sal. mínimos }\end{array}$} & Masculino & 341 & 430 & 479 & 555 & 651 & 809 & 1.073 & 1.055 & 898 & 694 & 750 \\
\hline & Feminino & 2.917 & 2.991 & 3.271 & 3.154 & 3.660 & 3.770 & 4.203 & 4.188 & 2.926 & 1.958 & 2.270 \\
\hline \multirow{2}{*}{$\begin{array}{l}\text { De } 2,01 \text { a } 3 \\
\text { sal. mínimos }\end{array}$} & Masculino & 114 & 138 & 152 & 207 & 235 & 285 & 333 & 284 & 337 & 306 & 346 \\
\hline & Feminino & 327 & 275 & 240 & 410 & 390 & 519 & 608 & 493 & 532 & 467 & 540 \\
\hline \multirow{2}{*}{$\begin{array}{l}\text { De 3,01 a } 4 \\
\text { sal. mínimos }\end{array}$} & Masculino & 41 & 46 & 56 & 61 & 67 & 99 & 123 & 90 & 88 & 81 & 90 \\
\hline & Feminino & 126 & 87 & 77 & 95 & 103 & 132 & 143 & 160 & 152 & 135 & 149 \\
\hline \multirow{2}{*}{$\begin{array}{l}\text { De } 4,01 \text { a } 5 \\
\text { sal. mínimos }\end{array}$} & Masculino & 10 & 24 & 27 & 17 & 17 & 26 & 40 & 32 & 31 & 26 & 41 \\
\hline & Feminino & 34 & 36 & 46 & 28 & 35 & 52 & 59 & 47 & 59 & 55 & 50 \\
\hline \multirow{2}{*}{$\begin{array}{l}\text { De } 5,01 \text { a } 7 \\
\text { sal. mínimos }\end{array}$} & Masculino & 10 & 16 & 12 & 14 & 12 & 17 & 17 & 11 & 20 & 23 & 15 \\
\hline & Feminino & 26 & 22 & 25 & 29 & 20 & 22 & 48 & 31 & 33 & 33 & 48 \\
\hline \multirow{2}{*}{$\begin{array}{l}\text { De } 7,01 \text { a } 10 \\
\text { sal. mínimos }\end{array}$} & Masculino & 7 & 9 & 8 & 10 & 7 & 7 & 7 & 9 & 8 & 7 & 8 \\
\hline & Feminino & 18 & 10 & 11 & 16 & 8 & 6 & 16 & 16 & 16 & 17 & 16 \\
\hline \multirow{2}{*}{$\begin{array}{l}\text { De } 10,01 \text { a } 15 \\
\text { sal. mínimos }\end{array}$} & Masculino & 4 & 5 & 4 & 2 & 1 & 3 & 5 & 2 & & 1 & 3 \\
\hline & Feminino & 5 & 6 & 9 & 6 & 6 & 1 & 8 & 10 & 7 & 9 & 9 \\
\hline \multirow{2}{*}{$\begin{array}{l}\text { De } 15,01 \text { a } 20 \\
\text { sal. mínimos }\end{array}$} & Masculino & 2 & 3 & 2 & 1 & 2 & 1 & 1 & 1 & & & \\
\hline & Feminino & 2 & 3 & 5 & 6 & 8 & 1 & 6 & 3 & 1 & & \\
\hline \multirow{2}{*}{$\begin{array}{l}\text { Mais de } 20 \\
\text { sal. mínimos }\end{array}$} & Masculino & 3 & 6 & 3 & 13 & 2 & & 2 & 1 & & & \\
\hline & Feminino & 3 & 4 & 3 & 5 & 7 & & 5 & 1 & 1 & 1 & 1 \\
\hline \multirow[t]{2}{*}{ Ignorado } & Masculino & 7 & 2 & 5 & 3 & 2 & 2 & 9 & & 1 & 2 & 4 \\
\hline & Feminino & 43 & 11 & 6 & 4 & 11 & 3 & 23 & 7 & 5 & 9 & 27 \\
\hline \multirow[t]{3}{*}{ Total } & Masculino & 924 & 1.160 & 1.237 & 1.345 & 1.555 & 1.884 & 2.439 & 2.404 & 2.850 & 2.866 & 3.220 \\
\hline & Feminino & 4.683 & 4.549 & 4.957 & 4.956 & 5.667 & 6.040 & 6.967 & 7.282 & 7.537 & 7.462 & 8.302 \\
\hline & Total & 5.607 & 5.709 & 6.194 & 6.301 & 7.222 & 7.924 & 9.406 & 9.686 & 10.387 & 10.328 & 11.522 \\
\hline
\end{tabular}

Fonte: Rais (MTE) - Elaboração dos autores.

3. Os resultados foram obtidos com base na Rais 2004. Por uma questão de limite de espaço, não anexamos a tabela. Contudo, vale ressaltar que não há variação significativa da escolaridade no sentido longitudinal, no período entre 1994 e 2004. 
preponderante vai de um a dois salários mínimos e, nesse nível de remuneração, a proporção relativa de mulheres é alta, característica do setor. Em níveis mais al tos de remuneração, a proporção diminui, com maior incidência de trabalho masculino. Há, além disso, uma particularidade: houve um crescimento relativamente maior de trabal hadoras na faixa mais freqüente, de 1 a 1,5 salário mínimo, enquanto na faixa imediatamente superior (1,5 a 2 salários mínimos) há um decréscimo, relativo e absoluto, no número de trabal hadoras, a partir de $2000 .{ }^{4}$ Isso indica que, mesmo em níveis de remuneração baixos, está ocorrendo uma desvalorização do trabalho feminino, que ocupa cada vez mais a franja na qual provavelmente imperam a precariedade nas relações de trabalho e a subcontratação. É necessário lembrar que a Rais constitui uma base de dados administrativa de alta confiabilidade, mas que cobre somente o setor formal, incluindo contratos de trabal ho temporário, mas não incorpora a informal idade, que é reconhecidamente freqüente no setor. Os resultados permitem a inferência de que tem havido, de forma correspondente, um crescimento na informalidade, contígua à faixa de mais baixa remuneração que tem registrado um crescimento relativa e absolutamente maior entre as mul heres trabalhadoras no setor.

\section{A confecção em um bairro de Goiânia: um estudo de caso}

Realizamos, de março de 2005 a janeiro de 2006, uma pesquisa num bairro de Goiânia próximo ao campus II da U niversidade Federal de Goiás, a Vila Jardim São Judas Tadeu. 0 bairro tem, segundo o Censo 2000, 4.744 habitantes (2.356 homens e 2.389 mul heres). Entre os 1.283 chefes de domicílios recenseados, a faixa de rendimento mensal predominante é a de um a cinco salários mínimos (59\%); o segmento mais freqüente $(24 \%)$ corresponde à faixa entre um a dois salários mínimos (Tabela 7).

A escolha do bairro São J udas como objeto de análise justifica-se pela possibilidade de explorar as redes de sociabilidade e de interação que integram as trabal hadoras do setor, el emento indispensável na pesquisa do trabalho domiciliar e da informalidade, que praticamente caracterizam o trabal ho em confecção no local. A liás, A lice de Paiva A breu, reconstruindo a contribuição de Courault e Haicault para a pesquisa do trabalho domiciliar na França, enfatiza que 0 trabal ho de campo seja "feito em comunidade ou mediante uma rede relações sociais". A ndréia Ferreira Campos, co-autora deste trabalho e bolsista de iniciação científica durante a realização da pesquisa, pertence à comunidade de trabalhadoras do bairro, trabal hando em tempo parcial num empreendimento de sua família desenvolvido num dos estabelecimentos de confecção do bairro. A ndréia realizou até 0 momento 14 entrevistas com trabal hadores do setor, sendo apenas uma com um interlocutor do gênero masculino, precedidas por entrevista exploratória com uma proprietária de confecção que não faz parte da comunidade do bairro. A entrevista exploratória, a experiência de vida de A ndréia na comunidade e a literatura disponível

Tabela 7 - Vila J ardim São J udas Tadeu: Porcentagem de chefes de domicílios por faixa média de rendimento (em salários mínimos).

\begin{tabular}{|c|c|c|c|c|c|c|c|c|c|c|}
\hline $\begin{array}{l}\text { Rendimento } \\
\text { (Sal. Mínimo) }\end{array}$ & até 0,5 & 0,5 a 1,0 & 1 a 2 & 2 a 3 & 3 a 5 & 5 a 10 & 10 a 15 & 15 a 20 & mais de 20 & $\begin{array}{l}\text { sem } \\
\text { rendimento }\end{array}$ \\
\hline $\begin{array}{l}\text { Chefes de } \\
\text { domicílio }(\%)\end{array}$ & 2 & 13 & 24 & 17 & 18 & 16 & 3 & 2 & 1 & 6 \\
\hline
\end{tabular}

Fonte: Elaboração feita a partir de CD-ROM da Secretaria de Planejamento do Município de Goiânia.

4. Verificamos que a faixa salarial média mais freqüente no setor em Goiânia é inferior à faixa predominante na região de Campinas-SP, conforme indica a pesquisa de Araújo e A morim (2002), para o período 1990-1998 (de um a três salários mínimos). Isso reforça a afirmação, ressaltada por diversos autores (Leite, 2004; L upatini, 2004), que um dos efeitos da reestruturação produtiva a partir dos anos 80 foi a constituição de uma "ponta precária" na cadeia de produção de alguns setores (e.g., automobilística e têxtil), incorporando mão-de-obra barata em greenfields ou regiões de industrialização atrasada, por meio de relações de terceirização ou subcontratação, geralmente no âmbito da precariedade e até da informalidade, em contraponto a um elo "virtuoso" localizado nos países economicamente dominantes, que absorve a alta tecnologia e, por outro lado, trabalhadores mais qualificados para atender aos requisitos da flexibilização das relações de trabalho. 
na temática do trabal ho domiciliar e do trabal ho feminino na confecção constituíram as primeiras matrizes para a elaboração de um roteiro para iniciar as 14 entrevistas subseqüentes.

A pesquisa foi orientada metodologicamente por princípios da sociologia interpretativa, principalmente da escola do interacionismo simbólico. 0 conjunto de trabal hadores entrevistados no bai rro São J udas Tadeu pode ser considerado como uma "amostragem teórica", no sentido conferido por Glaser e Strauss (1967) e reconstruído por defensores da metodologia qualitativa (Flick, 2004; A Ivesson e Sköldberg, 2000). 0 objetivo principal, em relação à amostragem, não é a representatividade estatística, mas a capacidade de fornecer insights "para a teoria em desenvolvimento, em relação à el aboração da teoria até o momento". As decisões em relação à escol ha das entrevistadas teve em vista "aquele material que prometa os maiores insights, observados à luz do material já utilizado e do conhecimento dele extraído" (Flick, 2004, p. 79). Privilegiaram-se, na realização dos roteiros e na análise das entrevistas, as técnicas da codificação teórica e da categorização (Strauss e Corbin, 1990): a codificação é entendida como representação das operações pelas quais os dados são fragmentados, conceitualizados e reconstruídos de novas maneiras, num processo de seleção gradual em que a interpretação do material textual é o suporte para decisões em relação à incorporação de novos casos. Houve também entrevistas realizadas pelo orientador com a própria A ndréia, procu- rando, em contraponto, afastar-se do roteiro e da codificação adotadas na etapa anterior, na tentativa de captar, mediante outra perspectiva, elementos ou relações evidenciados ou inferidos das transcrições das entrevistas realizadas. As entrevistas gravadas eram transcritas e, após breve intervalo, codificadas. A codificação gerava, de forma recursiva, perspectivas mais acuradas de leitura, assim como novas interlocuções geravam novos significados que, eventualmente, mereceram códigos inéditos e originaram releituras mais aprimoradas. A codificação e a análise das entrevistas foram intermediadas por um aplicativo de análise qualitativa, o A quad (cf. Huber, 1997).

Foi realizado um mapeamento preliminar dos estabel ecimentos do bairro em que ocorre o trabal ho na confecção e da divisão de trabalho nos estabel ecimentos (Tabelas 8 e 9).

Embora não tenhamos a pretensão de realizar um estudo empírico da cadeia de confecção, é necessário identificar algumas configurações típicas no bai rro São J udas, com base em esquemas de segmentos de cadeias do vestuário já reconhecidos e analisados na literatura (Cf. Leite, 2004). As formas mais comuns de cadeia de confecção no bairro São J udas Tadeu estão demonstradas na Figura 1.

A "cadeia A" representa o tipo de estabelecimento que está mais próximo da regulamentação e do emprego de vínculos formais. São microempresas de base familiar que vendem para confecções geralmente localizadas em shoppings ou centros comerciais. Estas produ-

Tabela 8 - Vila Jardim São J udas Tadeu: Número de estabelecimentos e de postos de trabalho no setor de confecção por tipo de empreendimento.

\begin{tabular}{|l|c|c|c|c|}
\hline & Confecções & Facções & Costureiras externas ou individuais & Total \\
\hline $\mathrm{N}^{\mathbf{o}}$ de estabelecimentos & 15 & 14 & 15 & 44 \\
\hline $\mathrm{N}^{\mathbf{0}}$ de postos de trabalho & 63 & 40 & 15 & 118 \\
\hline
\end{tabular}

Tabela 9 - Vila Jardim São Judas Tadeu: Número de postos de trabalho setor de confecção por função no processo de produção.

\begin{tabular}{|l|c|c|c|c|c|}
\hline & Corte & $\begin{array}{c}\text { Montagem } \\
\text { (overloque) }\end{array}$ & Montagem (costura) & Acabamento & Total \\
\hline Facção & 0 & 14 & 12 & 14 & 15 \\
\hline Confecção & 15 & 13 & 20 & 15 & 15 \\
\hline Externas & \multicolumn{5}{|c|}{15} \\
\hline
\end{tabular}




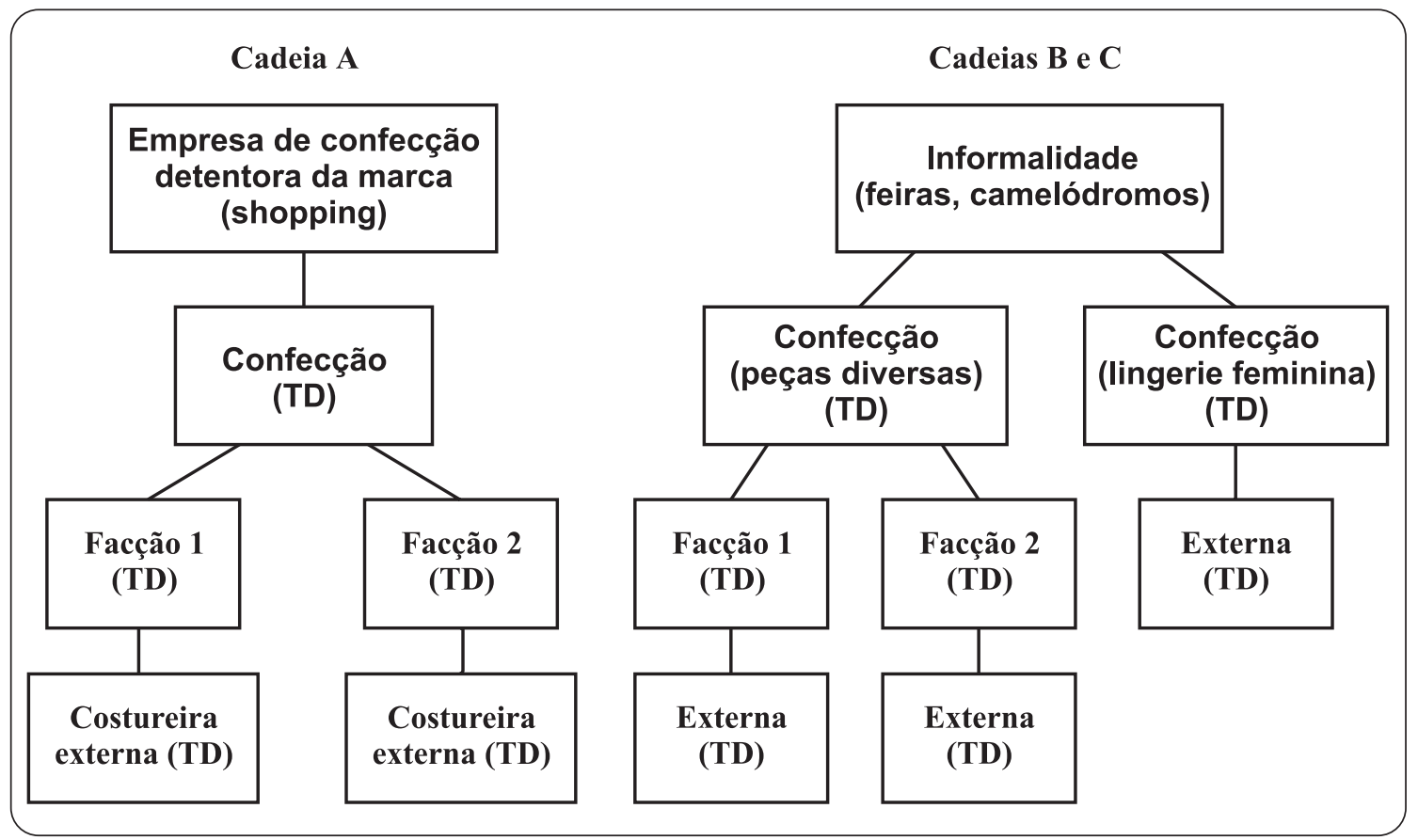

Figura 1 - Formas mais comuns de cadeia de confecção no bairro São J udas Tadeu

zem, mas também terceirizam uma parte de sua produção, recorrendo, via subcontratações, a confecções em bai rros periféricos. A s pequenas confecções no bairro São J udas Tadeu, empreendimentos de base familiar, ampliam a rede de subcontratações, empregando facções ou oficinas que realizam, geralmente, a montagem ou al guma de suas etapas. A s facções, por sua vez, empregam, dependendo do volume das encomendas, costurei ras externas, mulheres casadas, com filhos, mais experientes, que trabal ham em seus domicílios. A exploração intensiva e de caráter predador da mão-de-obra cresce nas extremidades da cadeia. Somente duas das entrevistadas são proprietárias de confecções do tipo representado no centro da cadeia $A$. Porém, vale ressal tar que a formal ização nessas duas empresas ainda está em processo e emprega a seguinte estratégia: registra-se apenas um empregado, uma pessoa da família, geralmente o marido ou uma filha, e o empreendimento como microempresa de base familiar. Todas os demais contratos envolvidos, tanto internamente como com facções ou costureiras externas, são informais.
As cadeias B e $C$, que representam a maioria no bairro pesquisado, estão no âmbito da informalidade. A cadeia B apresenta quase a mesma configuração que a cadeia $A$, com exceção do último elo superior: as peças produzidas são vendidas diretamente nas grandes feiras de comércio informal que ocorrem em Goiânia, como a Feira da L ua (aos sábados na Praça Tamandaré, localizada no Setor Oeste, região de al to poder aquisitivo) e a Feira Hippie (aos domingos, próximo à Estação Rodoviária). A cadeia C compreende pequenas confecções, geralmente de roupa íntima feminina, que fabricam peças completas, empregando esporadicamente costurei ras externas. Todas as cadeias envolvem, em al gum grau, o trabal ho domiciliar. Raras são as oficinas ou confecções que contam com instalações externas onde o espaço não traz uma ambigüidade de ocupação, entre o trabal ho doméstico e o trabal ho domiciliar na confecção, embora quase a totalidade das entrevistadas tenha manifestado a intenção de construir ambientes de trabalho externos.

Procurou-se, nas entrevistas realizadas, incluir cada tipo de relação com o estabele- 
cimento (proprietária de confecção ou facção, funcionária) e de função no processo produtivo (corte, costura, overloque e acabamento). ${ }^{5} \mathrm{Em}$ relação à idade, as donas de confecções ou facções tinham de 30 a 40 anos; já a maioria das funcionárias, de 20 a 30 anos, com exceção de duas com mais de 50 anos. Há, nesse aspecto, proximidade com rel ação à distribuição por idade na série 1994-2004 em Goiânia, na qual os vínculos empregatícios formais preponderantes de mulheres no setor de confecção se dão na faixa entre 25 e 29 anos, seguida pelos intervalos 30-40 e 18-24 (Rais 1994-2004). A ssim como ocorre no trabal ho domiciliar em todo o B rasil, é mais freqüente o trabalho de mulheres casadas com filhos: 10 entre as 14 entrevistadas são casadas e 11 têm filhos. 0 nível de escolaridade preponderante entre as entrevistadas esteve um pouco acima da média no trabalho formal em Goiânia: a maioria tem ensino médio completo, seguida pelo ensino fundamental completo. Contudo, a questão da desi gual dade relacionada à hierarquia de status ou de rendimento permanece entre as interlocutoras: a maioria das funcionárias costureiras apresenta escolaridade até o nível fundamental, enquanto as donas de facções ou confecções têm até 0 ensino médio completo. Os rendimentos das interlocutoras variavam de 350 a 450 reais para as funcionárias, elevando-se a aproximadamente mil reais para donas de confecções ou facções.

A importância da rede de sociabilidade em nível de contatos primários evidenciou-se na pesquisa em diversos aspectos relacionados à organização do trabal ho no setor, a começar da formação de profissionais. M ais de metade das entrevistadas aprenderam a costurar no círculo familiar (núcleo ou família extensa) e não tiveram nenhum tipo de remuneração durante todo o período de aprendizagem ou treinamento. A penas duas entrevistadas aprenderam como auxiliares em oficinas de confecção e três realizaram cursos de corte e costura. Não há relatos de cursos de aperfeiçoamento técnico nem de

5. Não há, no bairro, trabalhadoras que executem, em sentido restrito, as funções de criação ou design, bem como de modelagem (os modelos e moldes são copiados ou adaptados, com base em revistas ou diretamente de peças de confecção adquiridas ou emprestadas). formação nas áreas de criação ou design, ainda que a UFG ofereça, desde 1997, um curso de graduação em Design de Moda no período noturno. Pode-se dizer que a formação sistematizada nos cursos de corte e costura foi, para quem os realizou, insuficiente, principalmente em relação à parte prática, que só é al cançada com a experiência, como assevera A na M aria, hoje proprietária de uma das confecções do bairro São Judas: "Eu aprendi como tudo mais que você aprende, com a prática". A pesar de ter freqüentado um curso básico, A na queria confeccionar roupas íntimas e, para isso, passou a operar a máquina de uma vizinha, como aprendiz: "Ela me ensinou o básico, aí eu aprendi 0 restante. A gente vai se virando, porque os outros nunca ensinam o total, então se vocêquer aprender você tem que ter vontade própria e se aperfeiçoar".

Essa representação "naturalizada" do aprendizado e do treinamento profissional gera uma vantagem para as empresas de mai or porte, com a subcontratação de costureiras de meiaidade, com larga experiência em seus afazeres, que requerem força de trabalho de aplicação intensiva, mas pouca qualificação. 0 custo da formação de quadros é praticamente nulo e há, como ilustram várias declarações, uma representação social de que o aprendizado ocorre natural mente, em ambiente domiciliar, operando com máquinas que já existem no ambiente familiar, ou que estão próximas, nas casas de tios ou amigos da vizinhança. É necessário "conformar-se" às condições precárias do trabal ho domiciliar, e a habilidade para a costura é um dom e não um produto de incorporação racional e sistemática, mediante treinamento supervisionado. Cida, com mais de vinte anos de experiência como costureira, inclusive em fábricas de porte médio, hoje proprietária de uma pequena confecção no bairro que emprega cinco costureiras, relata como ocorreu sua iniciação na costura:

A os seis anos de idade eu já me interessava em costura. Teve um dia que eu queria ir numa festa com minha irmã, eu não tinha nenhuma costureira e nem nada e queria uma roupa nova [...]. Eu pedi para minha irmã comprar um pano, aí eu fiz a roupa escondido da minha mãe, 0 vestido era um modelo tubinho que usava na 
época, eu peguei um vestido e coloquei por cima do pano e cortei um para cada uma. Eu mostrei para minha irmã e ficou muito bonito, só sei que eu costurei sem nunca ter feito nada antes. (Cida)

Márcia, auxiliar de costura numa facção, reforça a representação da "aprendizagem natural": "Eu aprendi tudo de forma muito rápida, eu acho que eu já tinha al guma habilidade. Pelo que eu me lembre, eu não gastei mais que uma semana para ficar boa mesmo em tudo, por isso, minha mãe diz que eu já tinha o dom".

N essa representação o trabalho domiciliar articula-se com o trabal ho doméstico, ainda que, em sua conceituação, eles sejam até opostos. ${ }^{6}$ A inda que a atividade de costurar para o próprio núcleo familiar esteja, há muito, em desuso, é difícil caracterizar a costura realizada no próprio domicílio como uma atividade radicalmente diferente de cozinhar, limpar ou lavar/passar roupa. A máquina de costura, no bairro estudado, praticamente faz parte do mobiliário doméstico. A prática da costura está alinhada, juntamente com outras atividades, no âmbito das "prendas domésticas" que fazem parte da formação da mulher e integram a "educação para o lar". A ssim, numa sociedade que ainda guarda uma dimensão patriarcal, o trabalho domiciliar na confecção é "tolerado" desde que não entre em choque com a vida familiar, que não prescinde do trabal ho doméstico, real izado preponderante

6. Cristina Bruschini e Sandra Ridenti (1993) elaboraram uma reconstrução da literatura sobre 0 trabal ho domiciliar, considerando que a maioria dos trabalhos privilegiava 0 trabalho em domicílio subcontratado por empresas e propunha, no próprio artigo, enfocar o trabalho domiciliar por conta própria, inspirado numa pesquisa anterior feita por Luís A ntônio Machado da Silva (1979). 0 trabalho informal das costureiras mais experientes (costureiras externas) de famílias de baixa renda constitui uma das poucas for mas de trabalho domiciliar autônomo. 0 conjunto de atividades da "costura", segundo Silva, "concretiza empiricamente de forma mais clara a contradição entre trabalho domiciliar e trabalho doméstico", pois tais atividades não são indispensáveis para o desempenho do trabalho doméstico (como são cozinhar e limpar), embora possam se apresentar, em alguns aspectos (como cerzir meias, remendar roupas ou pregar botões), como tarefas rotineiras e essenciais. Podem configurar, por outro lado, um saber especial como trabalho em domicílio, embora se afastem da esfera costumeiramente doméstica em razão do equipamento que requerem. Assim, "a costura enquanto atividade concreta estaria dentro e fora do âmbito do trabalho doméstico" (Silva, 1979, p. 198) ou exclusivamente por mulheres no âmbito familiar (mães, filhas, sobrinhas). 0 depoimento de A na Carla é sintomático do que poderíamos chamar subordinação do trabal ho domiciliar ao trabalho doméstico:

Eu nunca tenho tempo para a costura. De manhã eu me levanto, tenho que fazer o café, arrumar as crianças para a escola, arrumar 0 marido para ir trabalhar, arrumar os filhos também, depois arrumar a casa. Depois de tudo, vem $o$ almoço, faço 0 almoço, depois do almoço é que eu vou trabal har. Sento na máquina, fico por lá até mais ou menos umas seis, seis e meia da tarde; paro, volto para a cozinha, faço o jantar. À noite eu não costuro mais. Quando eu comecei, costurava até uma hora da madrugada, mas depois me deu um problema sério de coluna e nas vistas, que agora não dou conta mais de trabal har à noite.

Por outro lado, a uma empresa não interessa a flexibilidade de horário requerida por trabaIhadores de baixa qualificação em virtude de suas atividades e "obrigações" em âmbito doméstico. Os contratos informais, o pagamento por peças produzidas, a contratação temporária em períodos de maior demanda e outros procedimentos que bem configuram a chamada precarização nas relações de trabal ho são, portanto, tacitamente aceitas pel as trabal hadoras no setor, sendo até consideradas vantajosas em virtude das condições socioculturais que articulam trabalho doméstico e trabalho domiciliar. A entrevista com M árcia, que trabal ha, juntamente com sua irmã e sua prima, na facção de sua mãe, relata como os serviços do empreendimento familiar eram contratados: "No início eles vinham, mas não tinha nada por escrito, como um contrato. Eles vinham e passavam o serviço e davam uma data certa de entrega. Depois disso, nós tínhamos que entregar nessa data, ainda hoje é dessa forma". 0 depoimento de Célia, costureira externa subcontratada, 31 anos, casada, com dois filhos, é exemplar no sentido de ilustrar al gumas características essenciais do trabalho na confecção no bairro pesquisado: imbricação entre trabal ho doméstico, trabalho domiciliar e redes de sociabilidade:

Eu trabal hava fora como secretária, em outro ramo. $M$ as por causa das crianças e das coisas 
de casa, passou a ficar difícil para sair todos os dias e trabalhar fora. Aí eu procurei algo para fazer dentro de casa. Uma vizinha [sogra da irmã da entrevistada] ofereceu pra me ensinar pra depois eu ajudar ela. Eu aceitei e comecei. Fiquei lá por volta de quinze a vinte dias, sem receber nenhuma remuneração. [...] N ão assina a carteira, é somente através de um trato verbal. Eu soube através da minha mãe que esta pessoa estava precisando de alguém pra trabal har com el a e como eu estava fazendo pra outra pessoa que tinha quatro costureiras e 0 serviço estava pouco para nós. Eu fui na casa da Cida e ela me falou que realmente estava precisando, e me deu algumas peças pra eu fazer. Eu fiz, entreguei, ela disse que estava bom, aí eu continuei e estou até hoje.

0 contrato "verbal" constitui a forma básica das relações de subcontratação, que constituem verdadeiras redes com vários níveis envolvendo confecções, facções, costureiras externas e auxiliares. M arina, proprietária de facção, afirma que "não há vínculo empregatício, é tudo só na palavra. A contratação éfeita pelo próprio dono, é ele quem traz e é ele quem busca". Estudos sobre redes de subcontratação no setores têxtil e de confecção (Ruas, 1993; A raújo e A morim, 2002) sustentam que esse tipo de relação direta com o elo superior na cadeia é mais comum em emprendimentos de base familiar. Os vínculos de subcontratação originam também a figura de um intermediário, que estabelece contatos entre a empresa de maior porte e as facções ou costureiras isoladas. Contudo, o contato direto prevalece no bairro pesquisado, onde a pessoa do "distribuidor de tarefas", contratado por empresas maiores, é mais rara, embora as trabalhadoras se refiram a essa forma indireta de subcontratação. Glória é proprietária de uma facção, em que trabalham ela própria, o marido, um de seus três filhos, uma auxiliar e duas costureiras contratadas. Sua empresa produz cerca de trezentas peças de jeans, dos mais diversos tipos (calça, jaqueta, bermuda, saia, macacão etc.) por semana. E m sua entrevista, Glória comenta as relações de subcontratação com os lojistas de confecção com quem trabal ha: "Eu só trato com o dono. N unca com segundos ou terceiros, é direto com o dono, porque às vezes o intermediário recebe 5 reais e me paga 3 reais e o patrão nem fica sabendo. D esde que eu era funcionária da empresa, eu nunca tratei com segundos e sim diretamente com o patrão".

0 trabalho nas facções e 0 de costureiras isoladas em regime de subcontratação representam realmente a ponta precária da cadeia de confecção. Condições de trabalho inadequadas, jornadas de trabal ho extensas somadas às horas de atividades em funções domésticas, ocorrência de lesões por esforço repetitivo, relações de competitividade e desconfiança entre colegas de trabalho, pagamento por tarefas, além de outras condições adversas, constituem o pano de fundo da organização de trabalho nesses estabelecimentos. A pesar disso, várias das entrevistadas ressal tam al gumas vantagens no trabal ho em facções. M arina, por exemplo, afirma ter muito orgulho de ser costureira e gosta de seu trabalho, apesar de considerá-lo excessivo: "esse trabal ho tem muitas vantagens. Por exemplo, eu ganho o meu dinheiro dentro de casa mesmo, não preciso sair em dia de chuva, debaixo do sol, e tenho mais liberdade na minha própria casa". Contudo, vê problemas em seu local de trabal ho: "é muito apertado. Ele tem um tamanho de três metros quadrados por três metros, tem cinco máquinas e quatro pessoas costurando o dia todo. Eu ainda ol ho uma criança muito peralta, e isso deixa a gente de cabeça quente. Eu coloco uma tel evisão no quarto para minha neta ficar quieta, assistindo". Considera difícil articular a vida doméstica com o trabalho na confecção: "N a verdade não sobra quase nada para eu fazer; como eu sou muito devagar e não tenho muita habilidade, eu tenho que levantar de madrugada eficar até mais tarde para adiantar o serviço. M eu esposo, eu só vejo na hora que el e chega do trabal ho e na hora que eu vou dormir e ele já está dormindo. Quando eu me levanto para costurar ele sai para trabaIhar". L orena, que tem 20 anos de idade e faz curso superior, descreve as condições na pequena confecção onde trabalha:

Lá é um quarto da casa, bem nos fundos do quintal, é pequeno, tem muita coisa lá dentro, é muito apertado, abafado. Tem uma janela enorme, mais que bate sol a tarde toda, é muito quente e mal ventilado. Toda a costura é feita lá dentro, menos o corte que é feito na cozinha. $N$ esse quarto tem bagunça da casa toda. 
Entre as costureiras mais antigas e experientes, a superposição de tarefas ébrutal, porque elas ainda assumem a logística, a coordenação e a supervisão do trabalho das auxiliares e a execução de tarefas mais especializadas, como o corte:

Eu tenho cinco costureiras, contando comigo. Eu sou a responsável pela compra, pelo corte e ainda por dar assistência para elas. [...] Sou eu quem corta tudo, quando eu mando para elas eu conto quantas peças foram, quando volta, eu conto novamente e confiro para ver se tudo está certo. Essa é a única forma de controlar. [...] Se eu colocar na cabeça que eu tenho que fazer tantas peças de roupa para amanhã, eu não tenho horário para parar, enquanto eu estiver agüentando, eu continuo trabal hando. Tem dias que eu trabal ho até a meia-noite, ou até uma hora da manhã. Todos os dias eu me levanto às cinco horas da manhã, eu nunca tenho horário para almoçar, meu dia é sempre corrido. Eu dou assistência para el as toda hora, uma costureira me liga, a outra me chama; então, eu nunca paro. (Cida)

E mbora o contato direto com a confecção facilite a negociação entre confecção-facção ou facção-costureira externa, fatores como a exigüidade dos prazos, o pagamento por empreitada, as condições precárias do ambiente de trabal ho e a ambigüidade dos papéis sociais relacionados a posições ocupacionais hierarquizadas e de relações sociais em nível igualitário, como laços familiares e de vizinhança, promovem relações de desconfiança e competitividade em nível interno às facções. M árcia, comentando as relações com os contratantes e com as colegas de trabalho, afirma:

Com os contratantes nunca houve [problemas], mas com os colegas de serviço, sim. Principalmente com a minha mãe, porque ela é a responsável pela entrega, pela mercadoria, e pelo atraso. A s brigas são só com ela. Ela exige demais da gente, ela quer que a gente levante às quatro horas da manhã para começar a costurar, mas isso não dá. Ela quer que a gente comece muito cedo e vá até muito tarde, no trabalho.

É impossível não remeter al guns problemas de relacionamento entre as colegas à questão das condições e do espaço do ambiente de trabal ho, que também ostenta uma ambigüidade que é distintiva da relação entre trabal ho domiciliar e vida doméstica. A percepção da precariedade do ambiente é mais acurada entre as entrevistadas que tiveram experiência com 0 trabalho em ambientes industriais de grandes confecções. Ainda assim, a maioria via o local de trabal ho como algo tumultuado, apertado e pouco arejado, sobretudo quando não há condições econômicas para a construção de um cômodo, um "Iugar fora da casa" para costurar ou cortar. As entrevistas, bem como as fotos feitas por A ndréia dos ambientes de trabalho, deixam bem claro o que A breu e Sorj (1993b) designaram como "superposição" do espaço no trabal ho domiciliar na confecção. 0 trabal ho é em geral realizado na sala, na cozinha ou em um quarto, ocasionando rearranjos constantes na disposição do mobiliário e no desempenho das atividades domésticas e implicando também uma adequação do tempo a elas destinado. Talvez essas reconfigurações do espaço e do tempo justifiquem um traço que a literatura considera também distintivo do trabalho domiciliar: a dificuldade ou incapacidade das trabaIhadoras de determinar o valor de custo das peças produzidas, incluindo fatores como tempo de depreciação de equipamentos, gasto de energia, tempo-trabal ho das trabal hadoras, mas também proprietárias e donas de casa, gastos com transporte, pesquisa, compra, comunicação etc. A preocupação limita-se aos insumos e a gastos com mão-de-obra, já que os outros fatores estão entrelaçados na contabilidade da vida doméstica e é quase impossível identificá-los e distingui-los nas condições culturais e sociais compartilhadas pela comunidade de trabalhadoras.

O caráter sazonal do trabal ho na confecção foi assunto em numerosas entrevistas. ${ }^{7}$ Pode-

7. A sazonalidade é considerada como um atributo da atividade de costurar que a distingue de outras atividades domésticas, como cozinhar, lavar e passar. Costura-se esporadicamente na esfera doméstica, enquanto as outras atividades mencionadas são de caráter contínuo e permanente. A ssim, como analisa Silva (1979), o próprio aprendizado da costura, em âmbito doméstico, torna-se menos "natural" do que o de lavar ou cozinhar. "Costurar pra fora" implica, portanto, um comprometimento menor em termos de sacrifício do tempo dedicado às tarefas domésticas do que lavar ou cozinhar "pra fora". 
se reconhecer os meses de novembro e dezembro como os de mel hores vendas e al gumas datas comemorativas como o Dia das M ães e o Dia dos $N$ amorados como épocas de maior trabal ho. Tal característica torna bastante propício o trabal ho feminino no setor, principalmente das costureiras externas, mas também eleva, até quase à general ização, as subcontratações nos elos inferiores da cadeia de confecção. U m terço das entrevistadas, que trabalham em facções com formas de subcontratação mais estáveis, estabelece um número fixo de peças para produção e as estocam para os períodos de pico. Porém, esse tipo de racionalização não é o que mais ocorre. A tendência é considerar a sazonalidade, principalmente pelas costureiras externas, como uma vantagem do emprego no setor, já que não as impede de realizar sem muito prejuízo as atividades da esfera doméstica ligadas à sua condição de mães e esposas. Por outro lado, 0 aspecto da sazonal idade estendese a outros tipos de ocupação no trabal ho feminino domiciliar (venda direta, teletrabal ho intermediado por celular ou computador, fabricação de brindes etc.), o que lhe confere uma identidade, mas também o desvaloriza, pois as atividades que Ihe estão associadas são consideradas secundárias e relacionadas a um tipo de trabalho em tempo parcial, cuja função é complementar 0 orçamento familiar. 0 trabal ho masculino domiciliar, quando ocorre, carrega outra identidade, pois está ligado a um reconhecimento da expertise, da competência técnica, de capacidade de empregar na própria casa 0 conhecimento técnico adquirido na empresa, na forma de assessorias ou serviços especial izados (cf. A breu e Sorj, 1993b).

As entrevistadas foram questionadas a respeito do que consideravam vantagens e desvantagens do trabal ho domiciliar na confecção. As respostas apontam a flexibilidade em relação ao tempo (período eduração da jornada) e à ocasião para trabal har como uma das principais vantagens. A na M aria enumera uma série de vantagens que foram também reconhecidas, em boa parte, em graus e nuanças diferentes, por outras trabalhadoras:

A vantagem é que você não tem horário para levantar, pra bater cartão, não tem que agüentar patrão, você pode trabal har na hora que você quiser, porque você é paga por produção, ganha pelo tanto que faz, além de tudo isso, o salário também é mel hor do que a carteira assinada. 0 assal ariado tem o patrão no pé, tem hora para chegar, tem hora para sair, tem horário para tudo. Para mim não é assim, eu trabal ho na hora que quero, no dia que quero, só trabal ha muito quem quer, pois, do contrário, não precisa morrer de trabalhar.

Curiosamente, o pagamento por peça, visto como benéfico, consiste numa das principais formas de exploração intensiva da mão-de-obra, pois a empresa contratante não se responsabiliza pelas condições de trabal ho ou pelos encargos sociais das costureiras sem vínculo formal, consideradas como autônomas. A pesar de toda ênfase na possibilidade de dispor de tempo livre, a literatura indica que parte considerável das trabalhadoras em domicílio está engajada em mais de uma atividade econômica, ainda que subsumida no próprio âmbito domiciliar, como a venda direta de produtos distribuídos por outras empresas (tipo Avon ou Herbalife) e a comercialização de produtos alimentícios feitos em casa (chocolates, biscoitos etc.). Seis das entrevistadas relataram trabal har ou ter trabalhado em mais de uma atividade econômica simultaneamente, duas delas por mais de dois anos.

Embora haja alguma ilusão na percepção da flexibilidade como não associada à precariedade das condições e à desregulamentação do trabalho, há também consciência do que se perde com a subcontratação: "A s desvantagens são aquelas relacionadas aos benefícios. Você não tem direito a fundo de garantia, salário-desemprego, isso no caso de você ficar sem serviço a qualquer momento. A qui se você perder 0 serviço você não vai ter nenhuma segurança, nada daquilo que a carteira assinada te oferece, nada daquele INPS que é descontado todos os meses" (A na M aria). A pesar da existência de al guma consciência da precariedade, em nível individual, existe alguma desconfiança com relação à organização em associações e à filiação a sindicatos ou cooperativas, por parte das entrevistadas. Glória, indagada a respeito das funções que um sindicato deveria realizar, afirmou: "sei que o pagamento é anual, mas sei também que eles brigam a favor do patrão, ao 
invés do funcionário, apóiam o patrão. Eles arrecadam muito e ajudam pouco". Emília, proprietária de uma confecção em outro bairro de Goiânia, com uma experiência de mais de vinte anos na produção, foi entrevistada numa fase piloto da pesquisa e enfatizou mais ainda a desconfiança com relação ao sindicato que atende aos trabalhadores do setor em Goiás:

Porque hoje o sindicato é só pra ganhar dinheiro, porque na hora que você precisa mesmo, não. N a A ssociação A tinha advogado, mas eu nunca utilizei, teve um dia que precisei do advogado, parece que só podia atender a gente se a mensalidade tivesse em dia, aí eu falei, não, eu nem sei se vai servir, na hora que eu precisar aí eu vou ter que pagar um advogado particular.

Se a comunidade de trabalhadoras na confecção pesquisada manifesta desconfiança ou descrédito em relação a sindicatos, associações e cooperativas, o inverso também ocorre, ou seja, há dificuldades para o reconhecimento de trabal hadores em domicílio como objeto da práxis sindical. A raujo e Sorj (1993b) identificam três motivos para tal descrédito: 0 trabalho em domicílio é uma atividade precária e obsoleta, incompatível com os requisitos do capitalismo e, por isso, em via de extinção; os trabal hadores na confecção exercem atividades que, em geral, não são regulamentadas e pertencem ao âmbito do informal, representando uma competição indevida com os trabal hadores formais; o movimento sindical construiu sua ação privilegiando a indústria e os grandes centros urbanos, pela homogeneidade das situações de trabalho que nelas se desenvolve, o que facilita a ação coletiva e sua organização.

Embora não se evidencie, no bai rro pesquisado, uma motivação para ações de representação de natureza sindical ou associativista, notase um resquício do papel regulamentador do sindicato da categoria em afirmações de algumas entrevistadas que são proprietárias de confecções ou facções. 0 salário especificado pelo sindicato é adotado como referência para o pagamento das profissionais subcontratadas e às vezes até acrescido em valor, a título de al guma compensação pelos encargos sociais que se perdem no vínculo informal. Glória, por exemplo, quando indagada a respeito do valor pago às costureiras, afirma: "É o salário do sindicato. Como a gente não assina carteira de trabalho, nós pagamos o salário bruto sem desconto. Em alguns casos a gente ainda dá uma gratificação. A o invés de pagarmos hora extra, a gente divide um real por peça para quatro pessoas, isso vai dar mais que hora extra". 0 valor do salário prescrito pelo sindicato tornase parte de um vocabulário de motivos ${ }^{8}$ que aparece em justificativas e apologias que evidenciam um processo de negociação permanente entre contratados e contratantes. No entanto, a animosidade entre as partes é menor quando os vínculos de sociabilidade primária, de parentesco e vizinhança são maiores, como o caso da comunidade estudada. 0 depoimento de Emília, a única entrevistada que não é do bai rro e cujo empreendimento está registrado e formal izado há muito tempo, testemunha que as pendengas judiciais entre patrões e empregados são mais comuns do que suspeitaríamos se restringíssemos o olhar apenas ao bairro São J udas:

Essa costureira foi até no sindicato sem ter razão. No dia 29 de outubro ela pediu acordo, e eu dei na hora, passei cinco anos e meio esperando isso. 0 relacionamento é difícil; elas sempre acham que estão te dando mais do que o salário paga, mas isso não é verdade, porque elas estão ganhando o combinado. Eu pago al to, essa que tá saindo ganha 700 reais, acima do salário do sindicato que é de 380 reais.

A dificuldade que se manifesta na construção de uma representação da categoria, bem como na constituição de associações, tem como correlatos problemas na formação de uma consciência profissional na categoria e até na construção de uma identidade profissional entre as trabalhadoras do setor de confecção no bai rro pesquisado. A prática da costura é vista positivamente, de maneira geral, entre as entrevistadas, independentemente da função no processo produtivo ou condição de empregador ou

8. Utilizamos o termo "vocabulário de motivos" no sentido expresso por Wright Mills, de definição "lingüística" de situações e interações, consistindo numa forma de agir e envolvendo um processo de negociação de identidades (cf Mills, 1970; Lyman e Scott, 1989). 
empregado. Contudo, trata-se de uma identidade muito ligada a atributos de uma trabal hadora em tempo parcial, subordinada às responsabilidades do trabalho doméstico. Os atributos da nova identidade em relação ao papel tradicional da "dona de casa" não são definidos em função dos produtos ou da obra que a costurei ra realiza, nem de uma atribuição de status diferenciada, mas da negatividade em relação a jornada, atribuições, e condições de um trabal hador em tempo integral.

Tenho muito orgulho em dizer que eu sou costureira. M uitas pessoas me perguntam e eu sempre respondo na hora. A pesar de trabal har muito, e às vezes me sentir muito cansada, eu gosto do que eu faço. Esse trabal ho tem muitas vantagens. Por exemplo, eu ganho o meu dinheiro dentro de casa mesmo, não preciso sair em dia de chuva, debaixo do sol, e tenho mais liberdade na minha própria casa. (M arina)

Eu não tenho o compromisso de chegar e sair na hora marcada do serviço, eu não dependo de patrão. Tem também a minha filha, eu tenho tempo de ficar em casa com ela, tenho mais tempo para ajudar ela nas tarefas de escola, eu posso ajudar mais el a do que se eu trabalhasse fora. (J oyce)

0 tempo também é uma vantagem, porque eu tenho tempo de ganhar meu dinheiro e também de cuidar de casa, quando eu preciso ir ao médico, vou tranqüila. Posso dizer que estou satisfeita com meu trabalho, se fosse pra eu escolher continuar com esse serviço ou trabalhar como assalariada eu nem pensava, continuava aqui. (A na Lúcia)

Há, sem dúvida, al gum nível de emancipação em relação ao tradicional domínio masculino, no que se refere à hegemonia de sua contribuição econômica. Contudo, várias das entrevistadas parecem não almejar a independência total nesse aspecto, enfatizando a autonomia no consumo e mantendo a heterenomia no provimento da renda familiar. Como a dominação de gênero no âmbito doméstico depende do ocultamento do valor das atividades femininas, tal atitude tem como conseqüência a renúncia a uma renovação dos valores que poderiam conduzir a uma relação familiar mais igual itária em termos do dispêndio laboral e de seu reco- nhecimento social. A na Carla, por exemplo, considera que a dependência em relação a seu marido diminuiu, embora a dupla jornada que agora enfrenta não Ihe permita aproveitar a sua autonomia relativa:

0 dinheiro que o meu marido me dá é a conta da despesa de casa. Às vezes, eu quero comprar alguma coisa, presentear alguém, dar algum dinheiro para o filho, eu não preciso mais depender dele, nem do dinheiro dele para fazer esse tipo de coisa. Eu faço o que eu quero, depois que eu ganhei o dinheiro ele é meu, aí eu gasto como quero. [...] Eu não tenho hora para o lazer. M inha vida é a casa, o marido, os filhos, e também o trabal ho.

\section{Consider ações finais}

São vários os termos empregados na literatura que sintetizam uma análise da rel ação entre trabalho domiciliar e trabal ho doméstico: subordinação, complementaridade, oposição, contradição, tensão. A despeito da limitação de nossa amostra e da incompletude na apresentação dos resultados, convém acrescentar uma contribuição às interpretações da relação conceitual que privilegiamos. Propomos compreender o trabaIho doméstico e o trabal ho domiciliar por uma mediação com as relações de gênero. Em relação ao trabal ho doméstico, a questão de gênero é mais simples: a mulher trabalha em casa, em âmbito privado; o homem na rua, espaço público; as atividades da mulher no trabal ho doméstico não requerem qual ificação, mas são assimiladas natural mente, graças a características biológicas das quais depende a reprodução da espécie e a convenções sociais tradicionalmente estabelecidas e transmitidas pelo processo de socialização. A dominação masculina no mundo do trabal ho doméstico tem como base ideológica uma justificação naturalista de papéis e atributos no espaço doméstico transformada em motivos de ação por uma série de máximas conversacionais, como: "o homem é natural mente desajeitado"; "a mulher deve cuidar da casa, deve ser prendada"; "aquele não é um trabal ho para mulher"; "a mãe deve dar educação para os filhos"; ; a mulher, em casa, deve servir o homem, que trabal ha todo dia". 
0 trabalho doméstico é um não-trabalho, pois não "dá dinheiro" e a mulher que trabal ha fora é uma não-mulher, ou seja, ela se masculiniza, pois o lugar do homem é na rua e as atividades domésticas são contrárias a sua natureza. A um tipo ideal da percepção do trabal ho doméstico que podemos designar como "naturalístico", corresponde um concepção essencialista de gênero. Facilmente identificaríamos os atributos culturais e papéis sociais determinados e socialmente reconhecidos da "mulher do lar" e do "homem trabalhador". Contudo, sabemos que, nas interações da vida doméstica cotidiana, ocorrem negociações não somente sobre papéis, mas também sobre atividades relacionados a gênero, em vários tipos de situações. Questões como "quem vai à feira", "quem cozinha nos fins de semana", "quem ajuda os filhos a fazer suas tarefas" e as decisões a que correspondem são construídas argumentativa e até performaticamente por atos lingüísticos. U m exemplo típico desses motivos relacionados à construção de identidades na esfera doméstica éo uso do termo "patroa" pelo marido, ao se referir à esposa ou à parceira com quem coabita. 0 termo não é usado diretamente nas conversas do casal, mas sempre obliquamente, a terceiros, conotando, ironicamente, um tipo de dominação feminina que ocorreria no lar e que constrangeria o homem, similar à dominação hierárquica que o marido, no caso, sofre por parte de seu chefe. No limite, a mulher se ocupa das tarefas domésticas, mas também tem autoridade sobre os gastos domésticos, tem poder sobre o orçamento da casa, independentemente de gerar diretamente rendimentos com atividades domiciliares. N esse caso, temos um tipo ideal "construcionista" da percepção do trabalho doméstico, ao qual corresponde uma concepção pragmática do gênero, ainda que submissa a valores que regem a acumulação capitalista.

E $m$ relação à percepção do trabalho domiciliar, que gera valor de troca de maneira mais perceptível, pode-se considerá-lo "tecnicamente", tendo em vista o desenvolvimento da produção e a acumulação do capital. A qui a divisão do trabal ho com base em capacidades e habilidades adequadas adquire relevo. No que se refere a uma divisão sexual do trabalho, motivos objetivistas e científicos relacionados à produção aliam-se a justificativas de ordem biológica ou até naturalística, como a velha distinção entre trabal ho manual, relacionado à criatividade e à espontaneidade, feminino, e trabal ho intelectual, racional, ligado à tomada de decisões, masculino. A divisão do trabalho doméstico não se altera, nesse caso, e as filhas passam a ajudar a mãe, que assume e "se conforma" com a dupla jornada de trabal ho. Há também uma possibilidade de articulação com uma percepção construcionista, levando até a inversão dos papéis tradicionais na esfera doméstica em função de uma produtividade maior. É o caso, por exemplo, presente no depoimento de Cida, em que o marido assume as tarefas domésticas e até al gumas etapas do trabalho domiciliar na confecção (ou seja, assume a própria dupla jornada), enquanto a mulher, com larga experiência na produção de confecções, responde pelo controle do empreendimento. Contudo, valores af etivos e familiares, que também integram a esfera doméstica, tornam-se subordinados a um tipo de individualismo empreendedorista:

M eus filhos não me ajudam em nada. M as meu marido me ajuda muito, em tudo. Ele leva 0 serviço para as costureiras, busca, ele faz os arremates para mim, conta as mercadorias para que eu faça as notas fiscais, ele me ajuda muito. Isso sem falar na parte doméstica que fica só por conta dele, é ele quem faz tudo. [...] M eu esposo não se importa comigo, para ele o que importa éo dinheiro. Eu também não ligo muito para ele, o que eu gosto mesmo é da minha turma de viagem, gosto muito dos meus colegas de trabal ho. Nosso relacionamento é bom, mas não pode ser considerada uma relação entre marido e mulher, émais uma rel ação de amizade. Ele se dedica mais ao bar e depois me diz que eu não tenho tempo para nada. Hoje meu filho veio me dizer que era para eu parar de costurar por hoje porque eu não dou atenção pra ele, mas eu respondi que ele não precisa mais de mim porque elejá tem 21 anos. M as eu parei um pouco e fiz o jantar para ele. N osso relacionamento ficou pior, se a gente pensar bem, porque eu não tenho tempo mais para eles, eu viajo muito, toda quinta para falar a verdade, e só vol to no sábado, durmo um pouco e me levanto às quatro e meia da manhã e vou para a feira. 
Q uando eu volto, eu almoço e vou dormir, de tarde eu vou à igreja. Se eu tiver algo para falar com eles é depois de tudo isso, mas acho que eles não podem reclamar, porque tudo que eu tenho hoje em dia eu consegui através da costura, foi tudo na máquina, a casa que eu construí, toda a criação dos meus filhos. Por isso, eu não reclamo de nada, e posso falar que estou satisfeita.

A articulação tecnicismo-construcionismo pode originar modelos de produção e gestão empresarial mais elaborados, com melhoria na qualidade da produção e também dos recursos humanos, mesmo envolvendo processos de terceirização e subcontratação. N esse caso, as inovações tecnológicas e organizações das empresas contratantes são transferidas e disseminadas ao longo da cadeia. Tal forma "virtuosa" de subcontratação não se verifica no bairro São Judas Tadeu, em que a porcentagem de empresas cadastradas e regularizadas, com racionalização técnica e administrativa de tipo industrial , éínfima.

O corre também uma percepção "humanística" do trabalho domiciliar, que valoriza os motivos, a subjetividade, a ética e os valores envolvidos nas relações e na organização do trabal ho. A rticulada a uma visão naturalística do trabal ho doméstico chega-se a uma representação que agrada particularmente as confecções maiores, contratantes, geralmente produtoras e distribuidoras, na cadeia de confecção, pois justifica o trabalho parcial, domiciliar, não regulamentado, apregoado como uma "concessão" da empresa, em face às duras exigências da produção e do trabal ho disciplinado, externo e em tempo integral, às necessidades da organização familiar. É o tipo de percepção que se coaduna com as relação de subcontratação e precarização das relações de trabalho, embora o caráter predador da força de trabalho nas extremidades da cadeia seja ainda maior na articulação naturalístico-tecnicista que vimos atrás, cuja conseqüência pode ser sintetizada num tipo de taylorismo doméstico na ponta precária da cadeia de produção. No entanto, a articulação entre objetivismo naturalista e humanismo apresenta também uma versão mais "virtuosa", que emerge com a criação de associações e cooperativas autogestionárias que realizam cursos de capacitação e orientam a formalização das empresas de base familiar, às vezes intermediadas por iniciativas governamentais, de ON Gs e de instituições do chamado "sistema S" (Sesc, Sesi, Senac, Senai e Sebrae).

Finalmente, chega-se a um tipo ideal da percepção da relação entre trabalho doméstico e trabal ho domiciliar que alia o construcionismo e o humanismo, valorizando as inovações organizacionais que privilegiam a subjetividade e diminuem a dominação por gênero, nem sempre compatíveis com o que se requer, ainda hoje, no sistema industrial ou mesmo com as exigências de uma pequena empresa de confecção. Compreenderiam, nas relações de trabalho investigadas, a tipos de atividades menos comprometidas com a produção e mais ligadas à distribuição e à comercialização dos produtos, anál ogas à de profissionais de venda direta, que requerem, para seu êxito, uma rede de relações cuja base é o núcleo familiar e a vizinhança. A inda assim, essa forma de percepção vigora, como representação social, quando, apesar de se gerar alguma renda com atividades como costureira independente ou trabalhadora em facção, a trabalhadora ainda considera estar "fazendo um bico". Pode-se também afirmar que essa percepção mais subjetivista do trabalho domiciliar é a que prevalece nos estágios de aprendizagem ou no início da profissionalização, quando ainda há incerteza sobre a permanência na atividade. Porém, a precariedade nas relações de subcontratação e o caráter de empreendimento familiar na maioria dos casos no bai rro estudado potencializam essa representação, fazendo com que as trabalhadoras se considerem desvinculadas, por muito mais tempo que 0 normal. L orena, por exemplo, trabalha, há seis meses, das oito e meia da manhã até as 6 da tarde, com intervalo de duas horas para o al moço, na montagem de roupa íntima feminina, em uma empresa de base familiar que confecciona de 150 a 200 peças por semana; ganha dez centavos por cada peça que monta. Quando questionada sobre como se sente em relação a suas atividades de trabalho, Lorena afirmou que se vê "como uma desempregada, fazendo um bico". 
0 esquema com o qual encerramos este trabalho (Figura 2) sintetiza as considerações anteriores, bem como sugere outras leituras e interpretações, embora a principal intenção ao divulgá-lo, ainda em fase de revisão e de novas incorporações a partir do material da pesquisa empírica, seja contribuir em estudos comparativos sobre o trabal ho domiciliar no setor de confecção

Finalizando as considerações, concordamos com a análise de que existe uma tensão entre trabalho domiciliar e trabalho doméstico na extremidade "precária" da cadeia de confecção. Propomos um esquema interpretativo para identificar e objetivar os fatores envolvidos na relação. Contudo, devemos esclarecer que, para melhor compreender o esquema, deve-se evitar o sentido metafórico mais usual no emprego do termo "tensão", que remete ao domínio da física (relativo ao uso de forças ou de campos elétrico ou magnético). Pensemos na tensão com referência ao domínio da música, ou melhor, da harmonia, com a al ternância entre movimentos de tensão e repouso numa mesma peça musical. A tensão pode ser até explicada por uma anál ise das freqüências e sucessões ou encadeamentos de notas, ou da estrutura musical, porém é um fenômeno que só se efetiva na percepção do ouvinte, que também está determinada natural ou biologicamente, mas também social e culturalmente. A ssim, a interpretação dos atos performáticos de construção de gênero e de identidade profissional ou ocupacional pode, quando a percepção da organização do trabalho é que está em jogo, nos dizer mais do que a análise do regime de acumulação ou de fatores relacionados à estrutura social.
A bstract: The confection sector employs intensively the women's labour, exhibits an heterogeneous structure and includes a diversity of production techniques. The sector is characterized by: predominance of micro and small companies, competitive and seasonal production; outsourcing and subcontract relations between companies of different sizes or located in distinctive phases of the production process. The main dojective here is to consider the domestic labour and the home labour by the perspective of gender relations, on the precarious link of the production chain, that includes the needlewomen work at home offices or at micro-factories. In the first part some considerations are made about the confection sector in Brazil and in the State of Goiás, introducing a qual itative research realized in a quarter located near the UFG campus, using for the most part half-structured interviews with women workers of the confection sector.

K ey words: domestic labour; clothing and confection industry; home labour.

\section{R eferências}

A BREU, A lice Rangel de Paiva. 0 avesso da moda. Trabal ho a domicílio na indústria de confecção. São Paulo: Hucitec, 1986.

A BREU, A lice Rangel de Paiva; SORJ, Bila. Trabalho a domicílio e relações de gênero: as costureiras externas no Rio de J aneiro. In:ABREU,A.R.P.; SORJ, B. (Orgs). 0 trabalho invisível: estudos sobre trabal hadores a domicílio no B rasil. Rio de J aneiro: Rio Fundo, 1993a. p. 43-61.

\begin{tabular}{|c|c|c|c|}
\hline & & \multicolumn{2}{|c|}{ Trabalho doméstico } \\
\hline & & Naturalis mo & Construcionismo \\
\hline \multirow[b]{2}{*}{$\begin{array}{l}\text { Trabalho } \\
\text { domiciliar }\end{array}$} & Tecnicismo & $\begin{array}{l}\text { Taylorismo } \\
\text { Dupla jornada } \\
\text { Papéis fixos } \\
\text { Dominação masculina } \\
\text { Valorização da produção }\end{array}$ & $\begin{array}{l}\text { Flexibilização nas funções } \\
\text { Flexibilidade na jornada } \\
\text { Negociação de papéis } \\
\text { Empreendedorismo } \\
\text { Utilitarismo e individualismo }\end{array}$ \\
\hline & Humanis mo & $\begin{array}{l}\text { Reestruturação produtiva } \\
\text { Jornada parcial, acomodada à esfera } \\
\text { doméstica } \\
\text { Negociação de papéis } \\
\text { Associativismo e cooperativismo } \\
\text { Valorização da regulamentação }\end{array}$ & $\begin{array}{l}\text { Organização, motivação e valores alternativos } \\
\text { ao padrão industrialempresarial } \\
\text { Autonomia no compromisso com a jornada } \\
\text { Pragmatismo e ativismo na construção do } \\
\text { gênero } \\
\text { Autogestão e solidarismo } \\
\text { Ambigüidade entre regulamentação e } \\
\text { informalidade }\end{array}$ \\
\hline
\end{tabular}

Figura 2 
. Trabal ho a domicílio - sociedades contemporâneas - uma revisão da literatura recente.. In: ABREU, A.R.P.; SORJ, B. (Orgs). 0 trabalho invisível: estudos sobre trabalhadores a domicílio no Brasil. 1993b, p. 11-24.

ALVESSON, M ats; SK ÖLDBERG, K aj. Reflexive methodology: $\mathrm{New}$ vistas for qualitative research. L ondon: Sage, 2000.

AM ORIM, Elaine Regina Aguiar. No limite da precarização? Terceirização e trabalho feminino na indústria de confecção. Campinas, 2003. Dissertação (M estrado em Sociologia) - Unicamp.

ARAÚ J O, Ângela M aria Carneiro; A M ORIM , Elaine ReginaA guiar. R edes de subcontratação e desigualdades de gênero e raça no Brasil. Cadernos Pagu. Campinas, v. 17/18, p. 267-310, 2001/2002.

BRUSCHINI, Cristina; RIDENTI, Sandra. Desvendando o ocul to: família e trabalho domiciliar em São Paulo. In: ABREU, A.R.P.; SORJ, B. (Orgs). 0 trabalho invisível: estudos sobre trabalhadores a domicílio no B rasil. p. 83-132.

CASTRO, Sérgio Duarte de. 0 arranjo produtivo de confecções da região de J araguá-GO 0 . R elatório de A tividades da Expansão da R edeSist. U CG/UFRJ , 2004. Disponível em: http://redesist.ie.ufrj.br/dados/ nt_count.php?projeto $=n t 41 \& \operatorname{cod}=5$. A cesso em: $15 /$ 12/2005.

FLICK, U we. U ma introdução à pesquisa qualitativa. Porto A legre: B ookman, 2004.

GA ZZONA , Raquel da Silva. Trabal ho feminino na indústria do vestuário. Educação e Sociedade. Campinas, v.18, n.61, dez. 1997.

GLASER, B.G.; STRAUSS, A. The discovery of grounded theory: Strategies for qual itative research. New York: A ldine, 1967.

GORINI, A .P.; SIQUEIRA, S. Tecelagem e malharia. Rio de J aneiro: BNDES Setorial, 1998.

HAGUENAUER, L et al. Evolução das cadeias produtivas brasileiras na década de 90 . Texto para discussão no 786. B rasília: I pea, abril de 2001.

HUBER, Günter $L$. Analysis of qualitative data with Aquad F ive for Windows. Schwangau: Huber, 1997.

LEITE, M arcia de Paula. Tecendo a precarização: trabalho a domicílio e estratégias sindicais. Trabalho, educação e saúde. Rio de Janeiro, v. 2, n. 1, p. 239265, 2004.

LIM A, Jacob Carlos; FER REIRA, Brasília Carlos. Trabalhadores urbanos no N ordeste. Trajetórias profissionais, mobilidade espacial e organização operaria. Revista Brasileira de Ciências Sociais. São Paulo, v. 30, p. 83-99, 1999.

LIM A, J acob Carlos. Qualidade e precarização: organização do trabalho na indústria do vestuário. Política e Trabalho. J oão Pessoa, v. 12, p. 61-103, 1996.

LU PATINI, M árcio Paschoino. As transformações produtivas na indústria têxtil: vestuário e seus impactos sobre a distribuição territorial da produção e a divisão do trabal ho industrial. Campinas, 2004. Dissertação (M estrado em Política Científica e Tecnológica) - Unicamp.

LYMAN, S. M.; SCOTT, M. B. A ccounts. In: A sociology of the absurd. 2ed. Dix Hills: General Hall, 1989 [1968]. p. 112-132.

M ILLS, C. W. Situated actions and vocabularies of motive. In: STONE, Gregory P. e FARBERMAN, Harvey A. (Eds.) Social psychology through symbolic interaction. Waltham: X erox College, 1970 [1940], p. 472-480.

M OREIRA, M aria Vilma. Cooperativismo e desenvolvimento: caso das cooperativas de confecções do M aciço de B aturité, Ceará. Política e Trabalho. J oão Pessoa, v. 13, p. 55-76, 1997.

MUNICÍPIO DE GOIÂ NIA. Secretaria M unicipal de Planejamento. Radiografia Social e Econômica de Goiânia eEntorno. Goiânia, 2004. CD-ROM .

PROCHNIK, V. Estudo da competitividade de cadeias integradas no Brasil: impactos das zonas de livre comércio - Cadeia Têxtil e Confecções. Nota Técnica Final. U nicamp-leneit-M DIC-M CT-Finep, dez./2002.

RUAS, Roberto. Notas acerca das relações entre trabalho a domícilio, redes de subcontratação e as condições de competição. In: A BREU , A .R.P.; SORJ, B. (Orgs). 0 trabalho invisível: estudos sobre trabaIhadores a domicílio no B rasil. 1993, p. 25-41.

SILVA, L uis A ntonio M achado da. A oposição entre trabal ho doméstico etrabal ho feminino remunerado. In: LOPES, J osé Sérgio Leite et. al. M udança social no N ordeste. A reprodução da subordinação (Estudos sobre trabal hadores urbanos). Rio de J aneiro: Paz eTerra, 1979. p. 195-210.

STRA USS, A.L.; CORBIN , J. Basics of qualitative research. London: Sage, 1990. 
